\title{
Growth of broadleaved species on post-agricultural lands introduced during the process of stand conversion with a use of artificial gaps
}

\author{
Tadeusz Zachara \\ Forest Research Institute, Department of Silviculture and Genetics of Forest Trees, Sękocin Stary, ul. Braci Leśnej 3, 05-090 Raszyn, Poland \\ Tel. +48 22 7150686; e-mail: T.Zachara@ibles.waw.pl
}

\begin{abstract}
This paper presents results on the restoration of Scots pine stands established on post-agricultural lands undergoing conversion into mixed stands. Sessile oak (Quercus petraea), common beech (Fagus sylvatica) and small-leaved lime (Tilia cordata) seedlings were planted in artificially created gaps ( 0.02 ha to 0.05 ha each) cut in six experimental plots (Forest Districts: Bielsk, Krynki, Sobibór, Dobieszyn, Skrwilno and Łupawa) located in 20-25-years-old pine stands. The experimental plots were spread across northern, central and eastern Poland and affected by root-rot fungus (Heterobasidion annosum). Nine years after planting, the number of individual trees and shrub species, their height sum and average height were calculated for fenced artificial gaps (LSO) as well as non-fenced artificial gaps (LSN) and compared to natural gaps (LN) and non-disturbed neighboring stands (D). Results were calculated separately for the planted species (oak, lime and beech) but combined for all other species. The results indicate satisfactory restoration in all of the investigated plots except in Krynki, which is located in a relatively poor site. Significant differences appeared between height sum as well as average height of planted species in fenced compared to non-fenced gaps. Furthermore, in both, natural and artificial gaps, the species composition of the young generation was enriched with natural regeneration of pioneer species, mainly silver birch (Betula pendula), rowan (Sorbus aucuparia) and aspen (Populus tremula).
\end{abstract}

Keywords: Scots pine, root-rot fungus, forest conversion, sessile oak, common beech, small-leaved lime

\section{Introduction and aim of the study}

Forest cultivation on post-agricultural land is one of the greatest challenges of modern forest management. A significant part of the stands growing in these areas are young plantings, which were introduced after 1995 as part of the National Programme of Increasing Forest Cover (Kaliszewski et al. 2016; MOŚZNiL 1995). As in the case of earlier afforestation efforts, large areas of even-aged stands were created, mostly the Scots pine Pinus sylvestris L., which is also threatened by infection caused by the fungus Heterobasidion annosum (Fr.) Bref. - the perpetrator of annosus root rot. Methods of safe stand cultivation under conditions threatened by this pathogen have been sought for a long time. Previous experience has shown that during sanitary cuttings, a so-called latent infection zone reaching 4-6 m into the stand should be considered (Sobczak 1990).
One way to counteract the destruction of young tree stands using this knowledge is to act pre-emptively by creating artificial gaps in places where the first symptoms of the disease are observed and to plant deciduous species there, simultaneously applying a fungus competing with the pathogen - applying Phlebiopsis gigantea (Fr.) Jülich to the stumps as a biological protection. This method (Sierota and Małecka 2004) was piloted in 2008-2011 under the supervision of the Forest Research Institute in 11 forest districts of northern, central and eastern Poland. The results obtained from these multifaceted studies illustrated the changes occurring in the reconstructed stands during the first 3 years after forming the gaps, with regard to further mortality of the pine trees, composition of the soil microflora and entomofauna, and growth of the regeneration (Sierota 2011). Eight years after commencing the research, the team, under the direction of Professor Sierota, conducted a study commissioned by the Directorate General

Received: 4.10.2019 r., accepted after revision: 19.11.2019 r. 
of State Forests, entitled, "The partial restoration of pine monocultures on former agricultural land threatened with root rot by applying the preparation Rotstop". One of the tasks of the project was to determine the dynamics of natural and artificial regeneration in natural and artificial gaps and in a comparative stand to assess the effectiveness of restoring pine stands using the above-mentioned method.

\section{Study site and methods}

Measurements were taken at six experimental plots, where methodological continuity and regularity of measurements were maintained in the previous period (Table 1).

There were four treatments of the experiment in each plot as follows:

- D - comparative stand (adjacent fragment of the stand with an area of 2 ares, with no signs of infection);

- LN - natural gap (a fragment of the stand with gaps caused by root rot, with natural regeneration appearing);

- LSN - artificial gap, made by removing the damaged stand, planted with 2-year-old seedlings of the target species (sessile oak, beech, small-leaved lime), individually mixed, not fenced and

- LSO - artificial gap, made and planted as above, fenced with metal mesh.

In the plots at Bielsk, Krynki and Sobibór, the average planting density was $1.5 \times 1.0 \mathrm{~m}$, and in the plots at Dobieszyn, Łupawa and Skrwilno, it was $1.5 \times 1.5 \mathrm{~m}$ (with local variations reaching 20\%). Seedlings were planted in spring 2008 .

The results presented in this study are from measurements taken in late autumn 2016 (Dobieszyn, Skrwilno) and in early spring 2017 (Bielsk, Krynki, Łupawa, Sobibór), that is, after nine vegetation seasons from planting. In each of the plots, the height of all artificial and natural regeneration was measured with an accuracy of $5 \mathrm{~cm}$, including shrub and tree species. Due to differences in gap size (whose area ranged from 2 to 5 ares), the number of young trees per 1 areis presented. The "height sum" of the regenerationin $\mathrm{cm}$ per $1 \mathrm{~m}^{2}$ as well as the average height of the renewals (in $\mathrm{cm}$ ) were also calculated. The results are compiled separately for the target species $(\mathrm{Db}$, $\mathrm{Bk}, \mathrm{Lp}$ ), other tree species and shrub species.

The results were analysed using Statistica 10 (StatSoft 2011), according to the "analysis of variance (ANOVA) for main effects" procedure as a source of variability, using two variables (treatment and area). The differences between the averages were compared with the Tukey test.

Only shrub species were omitted from the analyses due to the uneven distribution of the data.

\section{Results}

\subsection{Target species}

ANOVA showed significant differences between artificial and natural gaps and the comparative stands in terms of abundance. As for the total height and average height, a significant difference occurred between the fenced artificial gap and other experimental treatments (Table 2).

The differences between individual plots (Table 3) were not significant. Due to the layout of the experiment, it was not possible to calculate the interaction between the two factors (treatment and plot), but some trends can be seen in the attached figures (Fig. 1-3).

Oak and a small proportion of lime trees were planted in the Bielsk plot. The success of this cultivation turned out to be very high, with twice as many trees (Fig. 1), 7 times greater total height (Fig. 2) and 3 times greater height (Fig. 3) in the fenced gap after 9 years. In Łupawa, beech

Table 1. List of experimental plots subjected to restoration with a use of artificial gaps method

\begin{tabular}{lllccccc}
\hline $\begin{array}{l}\text { Regional Direc- } \\
\text { torate of the } \\
\text { State Forests }\end{array}$ & Forest District & Forest Subdistrict & $\begin{array}{c}\text { Forest } \\
\text { Comp. }\end{array}$ & Site type & Site index & Age* & Planted species \\
\hline Białystok & Bielsk & Jelonka & $55 \mathrm{i}$ & BMśw & Ia & 29 & Db, Lp \\
\hline Białystok & Krynki & Kruszyniany & $563 \mathrm{f}$ & BMśw & I & 33 & Db, Lp \\
\hline Lublin & Sobibór & Dubnik & 191 & BMśw & Ia & 33 & Db \\
\hline Radom & Dobieszyn & Strzyżyna & $177 \mathrm{Bh}$ & BMśw & I & 36 & Bk, Db, Lp \\
\hline Szczecinek & Lupawa & Święchowo & $308 \mathrm{i}$ & Bśw & Ia & 33 & $\mathrm{Bk}$ \\
\hline Toruń & Skrwilno & Huta & $259 \mathrm{a}$ & BMśw & Ia & 35 & $\mathrm{Bk}$ \\
\hline
\end{tabular}

Denotes: BMśw - fresh mixed coniferous forest, Bśw - fresh coniferous forest, Db - oak, Lp - lime, Bk - beech

* Stand age at the last measurement 
Table 2. Biometrical features of regeneration in natural and artificial gaps in comparison to neighboring stand after 9 years of experiment

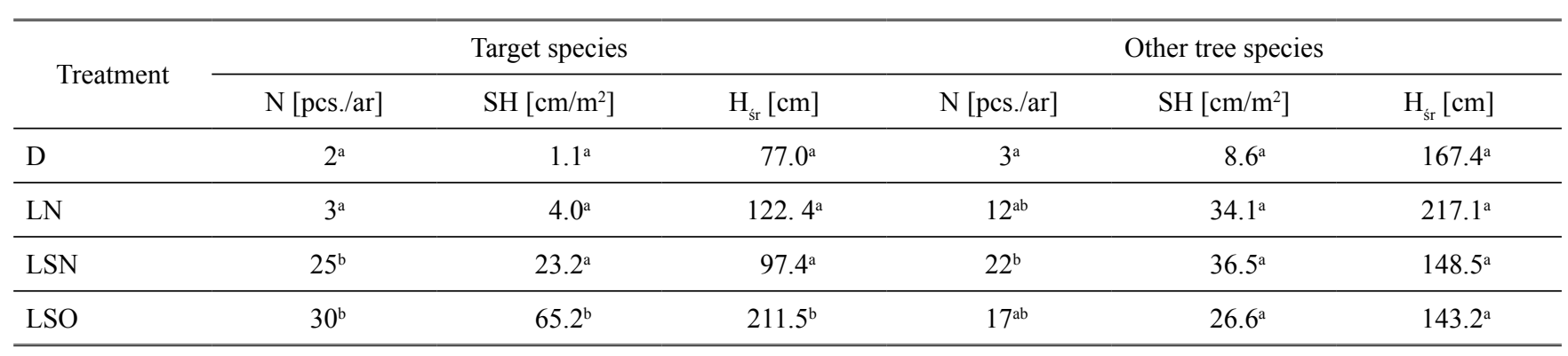

D - neighboring stand, LN - natural gap, LSN - non-fenced artificial gap, LSO - fenced artificial gap, N - number of trees, SH - height sum, Hśr - mean height, ${ }^{\text {ab }}$ - homogenous groups

Table 3. Biometrical features of regeneration on 6 plots after 9 years of experiment

\begin{tabular}{|c|c|c|c|c|c|c|}
\hline Forest District & \multicolumn{3}{|c|}{ Target species } & \multicolumn{3}{|c|}{ Other tree species } \\
\hline Bielsk & $21^{\mathrm{a}}$ & $42,8^{a}$ & $88,9^{a}$ & $19^{\mathrm{a}}$ & $26,4^{\mathrm{ab}}$ & $81,2^{\mathrm{a}}$ \\
\hline Krynki & $14^{\mathrm{a}}$ & $6,8^{\mathrm{a}}$ & $48,6^{a}$ & $5^{\mathrm{a}}$ & $4,9^{\mathrm{a}}$ & $74,8^{\mathrm{a}}$ \\
\hline Sobibór & $13^{\mathrm{a}}$ & $21,0^{\mathrm{a}}$ & $181,3^{\mathrm{a}}$ & $8^{a}$ & $23,1^{\mathrm{ab}}$ & $323,7^{b}$ \\
\hline Łupawa & $12^{\mathrm{a}}$ & $20,4^{\mathrm{a}}$ & $153,2^{\mathrm{a}}$ & $8^{\mathrm{a}}$ & $12,8^{\mathrm{ab}}$ & $147,6^{\mathrm{ab}}$ \\
\hline Skrwilno & $15^{\mathrm{a}}$ & $28,6^{\mathrm{a}}$ & $148,9^{\mathrm{a}}$ & $16^{\mathrm{a}}$ & $20,3^{\mathrm{ab}}$ & $93,7^{\mathrm{a}}$ \\
\hline
\end{tabular}

Denotes as in table 2

was the planted species, but oak, which self-seeded, was treated as the target species. The highest abundance of the desired species was achieved in the fenced artificial gap and slightly less abundance was noted in the unfenced gap (Fig. 1), while the average tree height was much higher in the fenced gap (Fig. 3).

In Skrwilno, planted beech developed well and was supplemented with self-seeded oak (as in Łupawa). The greater total height (Fig. 2) and the average height of trees in the fenced gap compared to the unfenced gap (Fig. 3) indicate the great importance of the browsing factor. At Sobibór, the only species introduced was oak, which encountered strong competition, especially from rowan and American black cherry. After cleaning, competitive pressure decreased slightly. In terms of abundance, there were more renewals of oak in the unfenced artificial gap (Fig. 1), but they were characterised by better growth, as expected, in the fenced gap (Figs 2, 3).

All three species were planted in the Dobieszyn plot and the oak which appeared there was self-seeded. The smallest number of oaks was recorded in the natural gap (Fig. 1). Nevertheless, the average height of oak was the highest there, as it was older than the ones planted in the artificial gap (Fig. 3 ). Growth in the fenced gap turned out to be slightly faster than in the unfenced gap.

The species (oak and lime) planted in the Krynki plot were characterised by slow growth, which may have been due to the habitat conditions (relatively low site index for pine trees, even though the habitat type of forest was defined as fresh mixed coniferous forest). Both the total heights (Fig. 2) and the average height (Fig. 3) of the target species were low, regardless of whether they grew in fenced or unfenced gaps.

The relationship between the different species treated as target species is illustrated in Table 4, which contains the minimum, maximum and average heights of these species' regeneration in the artificial gaps. As indicated in Section 2 , species composition of the regeneration varied among the plots, but there are some trends that can be verified in subsequent experiments. In the Bielsk plot, lime trees slightly exceeded the growth of oaks in both types of gaps. In Łupawa, no differences were found in the biometric parameters between the planted beech and the accompanying self-seeded oak, while in Skrwilno, the planted beech signi- 


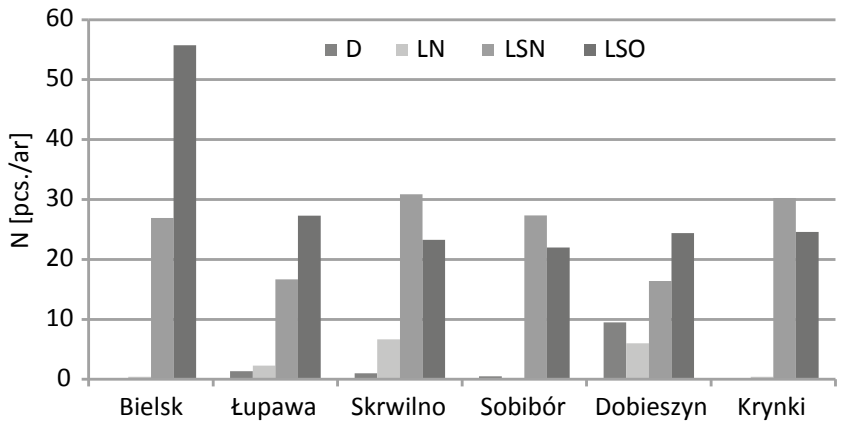

Figure 1. Number of target trees 9 years after start of experiment in 4 treatments on 6 plots

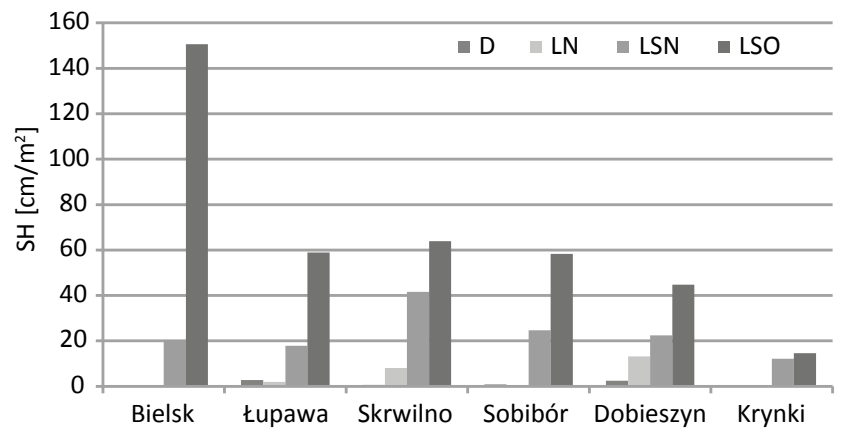

Figure 2. Height sum of target trees 9 years after start of experiment in 4 treatments on 6 plots

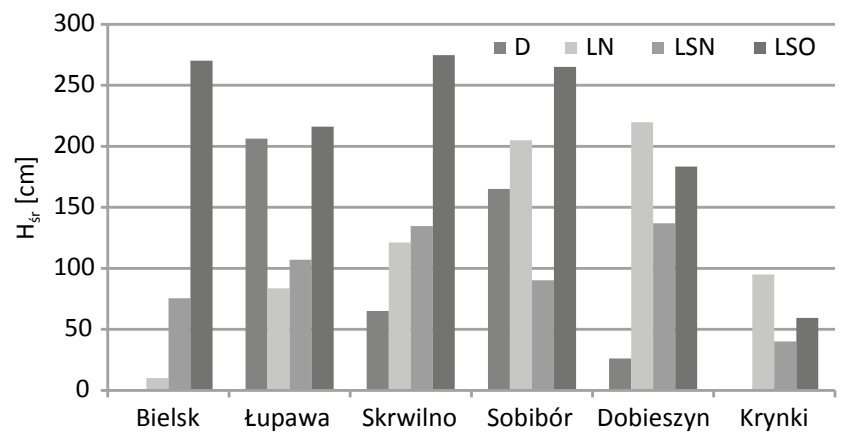

Figure 3. Mean height of target trees 9 years after start of experiment in 4 treatments on 6 plots

ficantly exceeded the oak. In Sobibór, of all three species, only oak was significant, as the single specimens of lime trees originated from self-seeding. In Dobieszyn, beech was characterised by the fastest growth in both gaps, while the slowest growth was found in oak in the unfenced gap and lime in the fenced gap. In Krynki, both planted species (oak and lime) grew slowly in both types of gaps. Similarto Dobieszyn, lime grew more slowly in the unfenced gap, while oak did so in the fenced gap.

\subsection{Admixed tree species}

The number of admixed tree species exceeded the number of target species in the comparative stand and the natural gap, whereas it was lower in the fenced and unfenced artificial gaps. Significant differences occurred between the unfenced artificial gap and the comparative stand (Table 2). The average height of the admixtures was higher in all treatments compared to the species introduced as targets, except for the fenced artificial gap. ANOVA did not show any differences between the experimental treatments. The same was true for the total heights of these species.

The differences between the plots in terms of the number of admixed renewals were not significant (Table 3 ), although one can observe a low amount in the plots in Krynki and Lupawa for all treatments and quite a high amount in the unfenced artificial gap in Bielsk (Fig. 4). Significant differences were found for the total height of this group of species between the plots in Krynki and Dobieszyn (Table 3).

Significant differences were also found for average height (Table 3). The lowest values occurred in the plots in Krynki, Bielsk and Skrwilno, while the highest value was found in Sobibór. In the latter area, the average height of admixtures was high in the natural gap, fenced artificial gap and in the stand (Fig. 6). High values were also recorded in the stand and the natural gap in Dobieszyn.

\subsection{Shrub species}

Admixed shrub species, mainly the buckthorn and American black cherry, occurred in large numbers only in Skrwilno and Sobibór. They did not occur at all in Lupawa and were of marginal importance in the remaining areas (Fig. 7).

The total heights of these species had high values in the comparative stand in Skrwilno and in the natural gap in Sobibór (Fig. 8).

The average height of these species had the highest values in the stand in Skrwilno, the natural gap in Sobibór (where, as opposed to the artificial gaps, they were not cutas a result of cleaning) and all the gaps in Dobieszyn (Fig. 9).

\subsection{Changes in species composition}

An illustration of the growth conditions of the regeneration is the summary table showing changes in the species composition (measured by the height sum of individual species) of the young generation of trees in the artificial gaps (Table 4). The year immediately after the broad-leaved species were planted was 2008/2009, and 2016/2017 was the year after nine growth seasons and after cleaning in the Bielsk and Sobibór plots. 
Table 4. Height of target species on particular plots in artificial gaps

\begin{tabular}{|c|c|c|c|c|c|c|c|}
\hline \multirow{2}{*}{ Plot } & \multirow{2}{*}{ Species } & \multicolumn{3}{|c|}{ Non-fenced plot } & \multicolumn{3}{|c|}{ Fenced plot } \\
\hline & & $\min$ & $\max$ & mean & $\min$ & $\max$ & mean \\
\hline Bielsk & lime & 25 & 170 & 98.4 & 70 & 530 & 291.2 \\
\hline Eupawa & beech & 35 & 250 & 107.0 & 45 & 525 & 225.8 \\
\hline \multirow{2}{*}{ Skrwilno } & beech & 25 & 260 & 143.1 & 85 & 430 & 284.1 \\
\hline & oak & 25 & 70 & 44.6 & 75 & 160 & 115.0 \\
\hline Sobibór & oak & 30 & 310 & 90.2 & 55 & 560 & 265.1 \\
\hline Dobieszyn & lime & 145 & 470 & 154.1 & 40 & 155 & 99.4 \\
\hline \multirow{2}{*}{ Krynki } & oak & 10 & 145 & 40.5 & 10 & 250 & 56.9 \\
\hline & lime & 15 & 95 & 34.9 & 15 & 140 & 65.6 \\
\hline
\end{tabular}

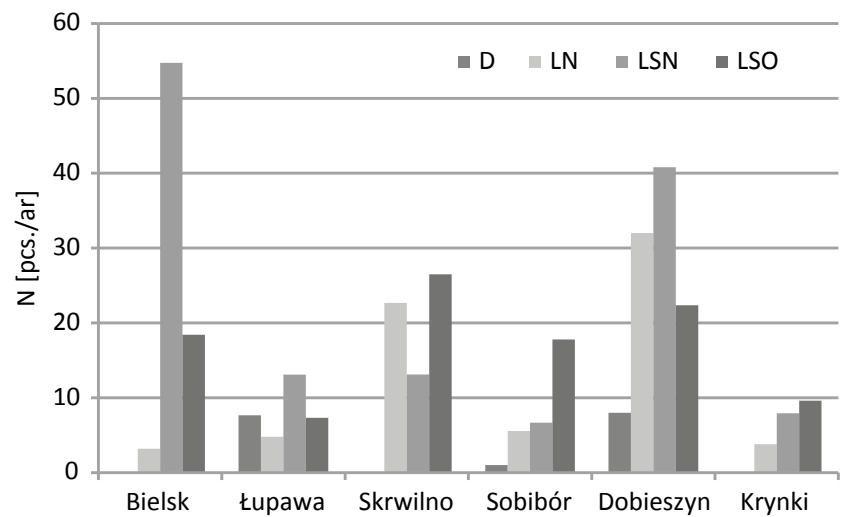

Figure 4. Number of admixture trees 9 years after start of experiment in 4 treatments on 6 plots

The comparison shows an increase in the share of windsown species, mainly the birch Betula pendula Roth, and to a lesser extent, the pine, aspen Populus tremula L., the rowan Sorbus aucuparia L. and the willow Salix caprea L., as well as shrubs, mainly the American black cherry Prunus serotina Ehrh.and the buckthorn Frangula alnus Mill., competing with the target species. The domination of target species by admixtures is particularly evident in unfenced gaps, as the latter are more effective in resisting the pressure of game

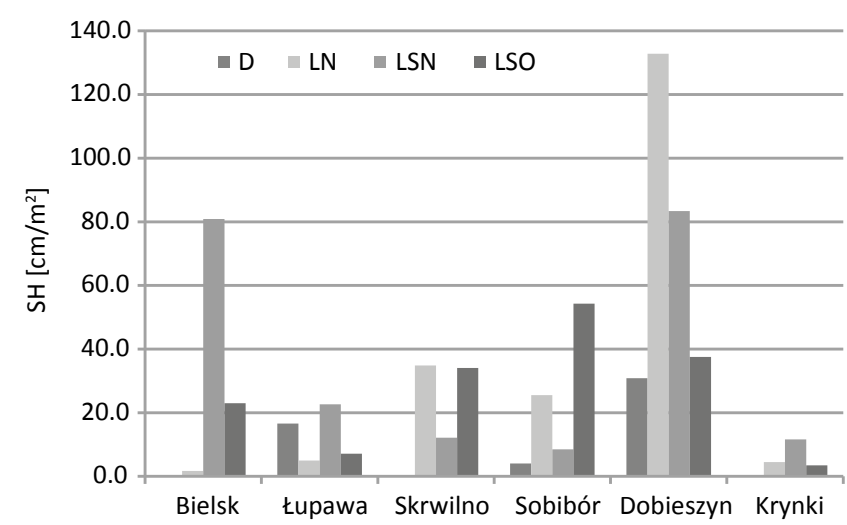

Figure 5. Height sum of admixture trees 9 years after start of experiment in 4 treatments on 6 plots

animals. The target species are in minority in the unfenced gaps (except for the area in Skrwilno), whereas they currently have a total share of at least $50 \%$ in the fenced gaps.

\section{Summary and discussion}

After 9 years from commencing the creation of artificial gaps, we can now make an initial assessment of the effectiveness of this undertaking. Geographically, the areas were 


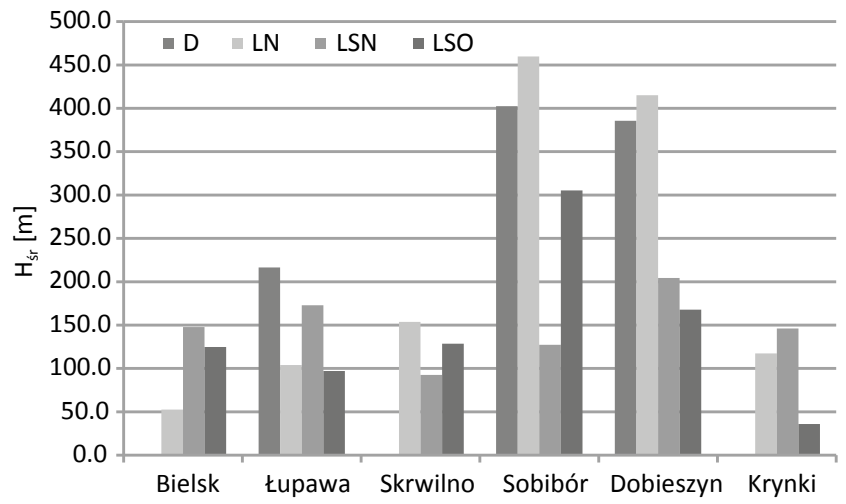

Figure 6. Mean height of admixture trees 9 years after start of experiment in 4 treatments on 6 plots

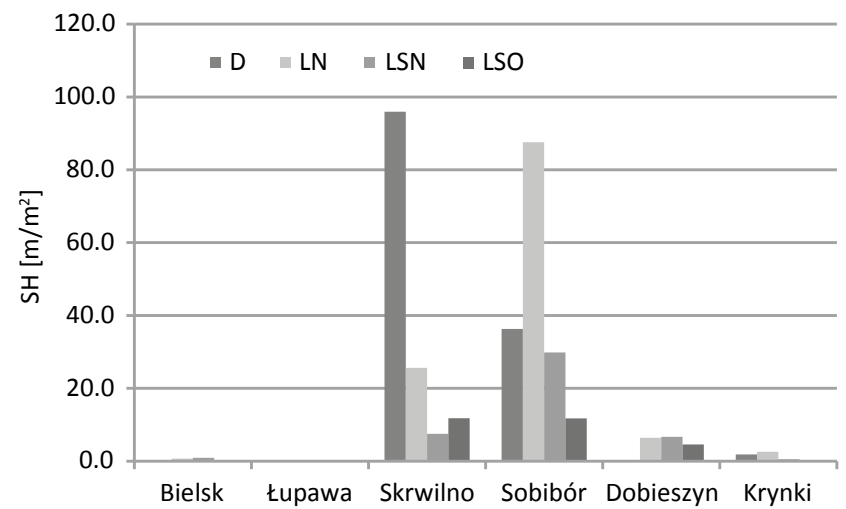

Figure 8. Height sum of shrubs 9 years after start of experiment in 4 treatments on 6 plots

located in the following natural and forest areas: I - Baltic (Lupawa), II - Mazurian-Podlasie (Krynki), III - Wielkopolsko-Pomorskie (Skrwilno), IV - Mazovian-Podlasie (Bielsk and Dobieszyn) and VI - Central Poland Uplands (Sobibór). In terms of habitat, all areas were classified as fresh coniferous forest or fresh mixed coniferous forest. The number and sum of regeneration heights on particular plots resulted from two processes - natural self-seeding by pine and admixed species, mainly sown by the wind, and the planting of oak, beech and lime trees (depending on the plot) in artificially made gaps. Some oaks also appeared naturally (probably due to sowing by birds), as evidenced by their presence both in the natural gaps and under the canopy of the comparative stand.

In terms of the reconstruction of species composition, the sites differed from each other, resulting from their spatial location (land, habitat, age of the surrounding stand). Although the introduced species (beech, oak and lime) became established in all the plots, growth was slow in some (especially in Krynki), which is not promising for an effective reconstruction process.

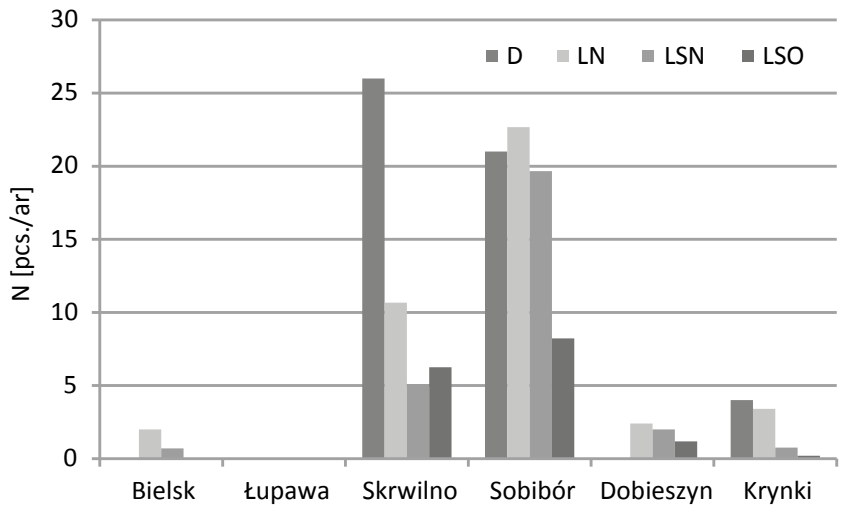

Figure 7. Number of shrubs 9 years after start of experiment in 4 treatments on 6 plots

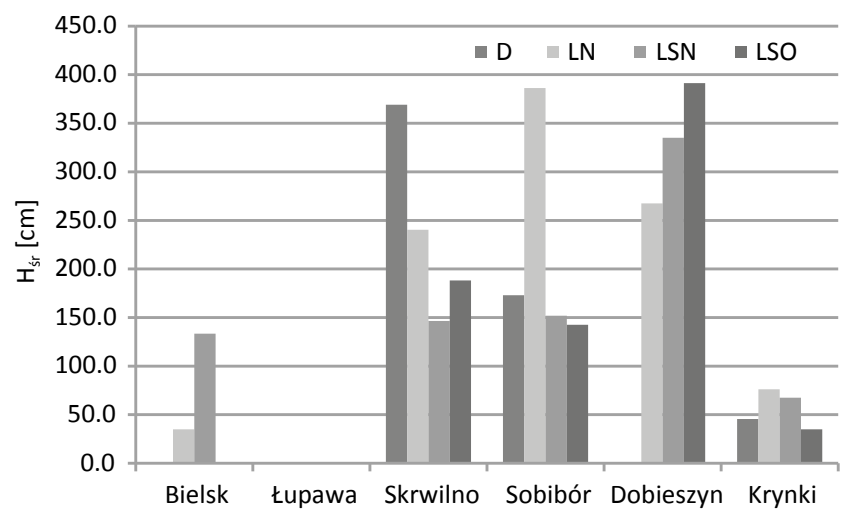

Figure 9. Mean height of shrubs 9 years after start of experiment in 4 treatments on 6 plots

Therefore, the method is of limited significance in post-agricultural land with the poorest fertility. However, the relatively good growth of the regeneration in Lupawa is of note, despite the fact that the forest habitat type is defined there as fresh coniferous forest. When interpreting this result, one should bear in mind the difficulties relating to the classification of former agricultural land using forest terminology (Sewerniak 2016), as well as the problems discussed in distinguishing coniferous and mixed coniferous forests (Brożek 2007). Another reason may be the fact that the only species introduced there was beech, and not oak or lime, which demands more fertile habitats. The relatively favourable climatic conditions (precipitation level) may also be important. In most of the districts, the height growth of the planted species proved to be satisfactory, at least in the fenced gaps. In areas where different species were introduced, a trend can be observed of the beech having the fastest growth among the three species, regardless of the presence of a fence. Furthermore, in the fenced gaps - free of the pressure of game animals -lime growth was slightly higher than that of 
Table 5. Species composition in artificial gaps in the year of planting and 9 years later on 6 experimental plots

\begin{tabular}{lcccc}
\hline \multirow{2}{*}{$\begin{array}{c}\text { Forest } \\
\text { District }\end{array}$} & \multicolumn{2}{c}{$2008 / 2009$} & & $2016 / 2017$ \\
\cline { 2 - 5 } Bielsk & LSN & LSO & LSN & LSO \\
\hline Lupawa & 8Db 2Lp & 9Db 1Lp & 5Brz 4 Bk 1Db Jrz Sw & 8Bk 1Db 1Brz \\
\hline Skrwilno & $10 \mathrm{Bk}$ & $10 \mathrm{Bk}$ & 7Bk 2Brz 1Czmam & 6Bk 3Brz 1Czmam \\
\hline Sobibór & $10 \mathrm{Db}$ & $10 \mathrm{Bk}$ & 5Czmam 4Db 1Brz Kr & 5Db 2Jrz 1Gb 1Czmam 1Gr \\
\hline Dobieszyn & $5 \mathrm{Db} \mathrm{3Lp} \mathrm{2Bk}$ & 4Db 3Lp 3Bk & 5Brz 1Jrz 1Db 1So 1Bk 1Lp & 3Db 2Brz 2Bk 1Jrz 1So 1Czmam \\
\hline Krynki & 7Db 3Lp & 7Db 3Lp & 5Brz 3Db 1Lp 1Wb & 5Db 3Lp 2So \\
\hline \hline
\end{tabular}

Denotes: Db - oak, Lp - lime, Bk - beech, Brz - birch, Wb - willow, Sw - spruce, Czmam - black cherry, Kr - buckthorn, So - pine, Jrz - rowan, Gb - hornbeam, $\mathrm{Gr}$ - pear

oak. There is no clear trend in this respect in the unfenced gaps. This may indicate that the lime tree is a species particularly vulnerable to browsing. A comparison of the growth of different species planted in the gaps at the same time needs to be verified using more homogeneous study material. The observed trends indicate that the group mixing of introduced species should be preferred. Problems caused by animal browsing confirm the opinion that fencing is an indispensable procedure for the introduction of deciduous species in post-agricultural land (Drozdowski et al. 2011).

A second important procedure from the point of view of the effectiveness of this reconstruction method is cleaning, freeing the seedlings and saplings from the developing shrubby vegetation (American black cherry, buckthorn) and wind-sown tree species. Birch is generally considered to be a desirable species, accelerating the formation of the forest ecosystem on former farmland (Bernadzki 1990; Jagodziński et al. 2017; Łukaszewicz 2018), so it should not be eliminated altogether, but only observed so that it does not dominate the slower-growing target species, which in turn may occur in large-sized gaps. Its expansion is more pronounced in artificial gaps than in natural ones due to the greater access of light in the former. However, this is not reflected in the results of all plots due to the cleaning performed (e.g. Bielsk). Generally, the thesis that birch is suitable in the silviculture of the main species can be confirmed, analogously as in the cultivation of oak on post-agricultural land, where it stimulates the height growth of the oaks (Andrzejczyk 2008). This requires frequent early and late cleaning operations.

Significant differences in the total height and average height of the regeneration species planted in the artificial gaps confirm the opinion that active breeding and protection measures, as an element of ecological engineering, can significantly shorten the period of reconstructing damaged young pine stands compared to passively waiting for the secondary succession that takes place in natural gaps (Bose et al. 2014; Gorzelak 1996; Szujecki 1990).

\section{Conclusions}

Nine years after establishing "artificial gaps", the following conclusions were drawn:

The introduction of oak, lime and beech seedlings in the artificial gaps can accelerate the process of pine stand conversion on former agricultural land, compared to selfseeding in natural gaps caused by root rot. However, especially in the case of oak and lime trees, the desired factor is adequate habitat fertility (starting from the fresh mixed coniferous forest habitat and higher), which enables the effective growth of these species.

The use of fencing is a prerequisite for the proper growth of deciduous species introduced in artificial gaps, since in unfenced gaps, their growth is inhibited by pressure from game animals.

Self-seeding by wind-sown species, especially birch, appearing in artificial gaps, plays an important role in growth stimulation of target species, but requires systematic early and late cleaning.

\section{Conflict of interest}

The author declares no potential conflicts of interest.

\section{Acknowledgements and funding sources}

The author thanks the General Directorate of State Forests for financing the research, Professor Zbigniew Sierota 
for his invitation to participate in the project and valuable discussions concerning the problem, representatives of forest districts for their cooperation during the project implementation and colleagues from the Forest Research Institute for their help with the fieldwork.

\section{References}

Andrzejczyk T. 2008. Wpływ brzozy brodawkowatej (Betula pendula L.) na wzrost i pokrój dębu szypułkowego (Quercus robur L.) w uprawach na przykładzie nadleśnictwa Krynki. LeśnePraceBadawcze 3: 203-209.

Bose A.K., Schelhaas M.-J., Mazerolle M.J., Bongers F. 2014. Temperate forest development during secondary succession: effects of soil, dominant species and management. European Journal of Forest Research133(3): 511-523.DOI 10.1007/ s10342-014-0781-y.

Bernadzki E. 1990.Koncepcje hodowli lasu na gruntach porolnych. Sylwan 3-12: 51-59.

Brożek S. 2007. Klasyfikacja siedlisk leśnych - uwagi w sprawie miejsca gleb w zasadach diagnozowania. Sylwan 2: 19-25. DOI 10.26202/sylwan.2005157.

Drozdowski S., Bolibok L., Buraczyk W., Wiśniowski P. 2011. Wpływ terminu sadzenia i sposobu zabezpieczenia przed zwierzyną płową na wzrost upraw dębowych na gruntach porolnych. Sylwan 9: 610-621. DOI: 10.26202/sylwan.2010076.

Gorzelak A. 1996. Ekologiczne uwarunkowania ksztaltowania lasów na gruntach porolnych. Sylwan 5: 29-34.

Jagodziński A.M., Zasada M., Bronisz K., Bronisz A., Bijak S. 2017.Biomass conversion and expansion factors for a chronosequence of young naturally regenerated silver birch (Betula pendula Roth) stands growing on post-agricultural sites.For- est Ecology and Management 384: 208-220.DOI 10.1016/j. foreco.2016.10.051.

Kaliszewski A., Młynarski W., Gołos P. 2016.Prospects for agricultural lands afforestation in Poland until 2020.Folia Forestalia Polonica Seria A. Forestry 58(3): 163-169.DOI 10.1515/ ffp-2016-0018.

Łukaszewicz J. 2018. Rola i udział brzozy w zalesieniach na gruntach porolnych,w: Grzywacz A. (red.) Gospodarka w lasach na gruntach porolnych (materiały z sesji naukowej). Polskie Towarzystwo Leśne, Supraśl, 87-105.

MOŚZNiL 1995. Krajowy program zwiększania lesistości. Ministerstwo Ochrony Środowiska, Zasobów Naturalnych i Leśnictwa, Warszawa.

Sewerniak P. 2016. Wpływ porolności na cechy gleby leśnej na tle problemów kartowania siedlisk porolnych w lasach,w: Zielony R. (red.) Siedliska leśne zmienione i zniekształcone. CILP, Warszawa, 49-62.

Sierota Z. (red.) 2011. Zmiany w środowisku drzewostanów sosnowych na gruntach porolnych w warunkach przebudowy częściowej oraz obecności grzyba Phlebiopsis gigantea.Instytut Badawczy Leśnictwa, Sękocin Stary, 279 s. ISBN 978-83-62830-00-8.

Sierota Z., Małecka M. 2004. Formowanie ,sztucznych luk” w celu ograniczania huby korzeni w drzewostanach sosny zwyczajnej i inicjowania przebudowy monokultur sosnowych na gruntach porolnych. Sylwan 1: 6-11. DOI. 10.26202/sylwan.2004101

Sobczak R. 1990. Teoretyczne i praktyczne aspekty zakładania upraw na gruntach porolnych. Sylwan3-12: 61-74.

StatSoft2011. Statistica (data analysis software system), version 10. www.stasoft.com.

Szujecki A. 1990. Ekologiczne aspekty odtwarzania ekosystemów leśnych na gruntach porolnych. Sylwan3-12: 23-40.

Tuszyński M. 1990. Właściwości gleb porolnych a gospodarka leśna. Sylwan 3-12: 41-49. 